ПРОЄКТУВАННЯ СИСТЕМИ ДОКУМЕНТУВАННЯ ОБЛІКУ ТОВАРІВ ТА УСТАТКУВАННЯ ОБ'ЄКТІВ ГОТЕЛЬНО-РЕСТОРАННОГО ГОСПОДАРСТВА ЯК ОДИН 3 ЕЛЕМЕНТІВ БЕЗПЕКИ ТУРИСТИЧНОЇ ДІЯЛЬНОСТІ

\author{
DESIGN OF THE SYSTEM OF DOCUMENTATION OF THE ACCOUNTING \\ OF THE GOODS AND THE EQUIPMENT OF THE OBJECTS \\ OF THE HOTEL AND RESTAURANT FACILITY AS ONE OF THE ELEMENTS \\ OF SAFETY OF TOURIST ACTIVITY
}

Удк 658.5:651.012:657.1

DOI: https://doi.org/10.32843/infrastruct59-8

\section{Малюга Л.М.}

к.е.н., доцент,

доцент кафедри туризму

та готельно-ресторанної справи

Уманський національний університет

садівництва

Терещук Н.В.

к.е.н., доцент,

старший викладач кафедри туризму

та готельно-ресторанної справи

Уманський національний університет

садівництва

Кожухівська Р.Б.

к.е.н., доцент,

доцент кафедри туризму

та готельно-ресторанної справи

Уманський національний університет

садівництва

\section{Maliuga Liudmyla}

Uman National University of Horticulture

Tereshchuk Nataliya

Uman National University of Horticulture

Kozhukhivska Raisa

Uman National University of Horticulture
У статті розглянуто процес проєктування діловодства у сфері обліку товарів та устаткування об'єктів готельно-ресторанного господарства. Наголошено на тому, що він є одним з елементів безпеки туристичної діяльності загалом та необхідним компонентом конкурентоспроможності будь-якого підприємства, що працює в ринкових умовах. Окреслено складність побудови облікового процесу об'єктів готельно-ресторанного господарства задля ефективного обліку та успішного управління запасами товарів. Для вдосконалення організаційного забезпечення, проєктування ефрективної системи документування обліку товарів та устаткування об'єктів готельно-ресторанного господарства виділено напрями руху товарів та господарські операції, які виникають у їх прочесі, уточнено склад об'єктів бухгалтерського обліку та контролю. Визначено необхідність відображення системи діловодства обліку товарів у Наказі про облікову політику підприємства та їі проєктування $з$ огляду на раціональність ведення бухгалтерського обліку та дієвість системи внутрішнього контролю для задоволення інформаційних потреб власників на всіх етапах руху товарів.

Ключові слова: діловодство, облік, проєктування об'єктів, товар, устаткування, безпека туризму, готельно-ресторанне господарство.

В статье рассмотрен процесс проектирования делопроизводства в сорере учета товаров и оборудования объектов гостинично-ресторанного хозяйства. Сделан акцент на том, что он является одним из элементов безопасности туристической деятельности в целом и необходимым компонентом конкурентоспособности любого предприятия, работающего в рыночных условиях. Определена сложность построения учетного процесса объектов гостинично-ресторанного хозяйства с целью эфорективного учета и успешного управления запасами товаров. Для усовершенствования организационного обеспечения, проектирования эффрективной системы документирования учета товаров и оборудования объектов гостинично-ресторанного хозяйства выделены направления движения товаров и хозяйственные операции, которые возникают в их процессе, уточнен состав объектов бухгалтерского учета и контроля. Определена необходимость отображения системы делопроизводства учета товаров в Приказе об учетной политике предприятия и ее проектирования с учетом рационального ведения бухгалтерского учета и действенности системы внутреннего контроля для удовлетворения информационных потребностей владельцев на всех этапах движения товаров

Ключевые слова: делопроизводство, учет проектирование объектов, товар, оборудование, безопасность туризма, гостиничноресторанное хозяйство.

The article discusses the process of designing office work in the field of accounting for goods and equipment of objects of hotel and restaurant facilities. It is noted that it is one of the elements in the safety of tourism activities and a necessary component of the competitiveness of any enterprise operating in market conditions. It is noted that inadequate information on all possible directions of movement of purchased and manufactured goods leads to ineffective management decisions and deterioration of the enterprise. Therefore, there is a need for effective design of the accounting of goods and equipment in their information support. This will ensure the consistency and relationship of indicators of accounting registers; will provide information of the required level of detail and generalization, to meet the needs of management. The complexity of the construction of the accounting process for the objects of the hotel and restaurant economy is highlighted for the purpose of effective accounting and successful management of stocks of goods. To improve organizational support and design an effective system for documenting the accounting of goods and equipment of objects, an analysis of the directions of movement of goods and business transactions that arise in their process was carried out; the composition of accounting and control objects was clarified. In the hotel and restaurant industry, there are three main groups of business transactions related to the movement of goods: the receipt of placement and disposal of goods. In general, the organization of accounting for goods at the enterprise also includes three main stages: methodological, technical and organizational. At the same time, at all stages it is important to have timely primary accounting and a clear procedure for organizing the compilation and processing of primary documents, which is called the schedule of documents. There is a need to reflect the system of record keeping of goods in the Order on the accounting policy of the enterprise and its design given the rationality of accounting and the effectiveness of internal control to meet the information needs of owners at all stages of movement of goods.

Key words: office work, accounting, design of objects, goods, equipment, tourism safety, hotel and restaurant facilities.

Постановка проблеми. Одним 3 елементів безпеки туристичної діяльності є ефективне фрункціонування об'єктів готельно-ресторанного господарства. Світові тенденції індустрії демонструють, що сорера діяльності готельно-ресторанного бізнесу має високий дохід і стрімкі темпи розвитку.
Ресторанний бізнес одночасно включає чисту роздрібну торгівлю покупними товарами та роздрібний продаж кухонної продукції, виготовленої на власному устаткуванні для її споживання у ресторані, а це означає, що базовими передумовами ефективного фрункціонування готельно-ресторанного 
господарства $€$ достатній обсяг, раціональне використання й ефективне управління запасами товарів.

В основу ефрективного обліку та успішного управління запасами товарів покладено необхідність використання різноманітної облікової інфрормації. Це зумовлює необхідність пошуку концепцій та моделей, що дадуть змогу оптимізувати та раціоналізувати інорормаційне забезпечення менеджменту підприємства.

Неналежне інформаційне забезпечення всіх можливих напрямів руху покупних і виготовлених товарів приводить до прийняття неефективних управлінських рішень та погіршення показників діяльності підприємства, тому виникає потреба проєктування документообігу обліку товарів та устаткування в інфрормаційному забезпеченні щодо прийняття управлінських рішень.

Аналіз останніх досліджень і публікацій. Дослідженню проблематики документації та документообігу в системі бухгалтерського обліку присвячені наукові праці провідних вітчизняних учених, таких як М. Бондар, 3. Гуцайлюк, М. Дем'яненко, В. Жук, Я. Крупка, Ю. Кузьмінський, С. Легенчук, М. Огійчук, В. Палій, М. Палюх, В. Пархоменко, М. Пушкар, Я. Соколов, В. Сопко, Л. Сук, П. Хомин, В. Швець. Однак низка організаційних аспектів діловодства та документообігу в системі бухгалтерського обліку продовжує залишатися дискусійною й потребує подальшого дослідження.

Постановка завдання. Метою дослідження $€$ аналіз процесу проєктування діловодства у сорері обліку товарів та устаткування об'єктів готельноресторанного господарства й основних фракторів, що на нього впливають.

Виклад основного матеріалу дослідження. Для побудови облікового процесу об'єктів готельно-ресторанного господарства складною $є$ проблема визначення сутності, складу та функцій документів у бухгалтерському обліку.

Термін «документ» $є$ базовим поняттям ієрархічної будови, що забезпечує фрормування та збір інфрормації у багаторівневому процесі управлінського та бухгалтерського обліку шляхом збирання, оброблення та узагальнення показників, що характеризують господарські операції забезпечення ефективної діяльності.

Зміст необхідної користувачам інфрормації визначається завданнями, що ставляться системою менеджменту як безпосередньому користувачу інфрормації під час прийняття управлінських рішень. Одержання конкретних результатів від використання облікової інфрормації забезпечить підпорядкування документів вирішенню конкретних завдань 3 управління бізнесом (зростання доходів за видами діяльності або видами продукції, зниження витрат, оптимізація дебіторської заборгованості тощо).
3 іншого боку, щоб документи забезпечували інформаційні потреби інших етапів облікового процесу, під час фрормування переліку показників слід виходи з переліку та змісту регістрів аналітичного та синтетичного обліку й фрорм звітності. Це забезпечить послідовність, взаємозв'язок та наступність показників документів, облікових регістрів та фрорм звітності, дасть змогу одержати інформацію потрібного рівня деталізації та узагальнення, тобто задовольнити потреби управління.

Метою ведення бухгалтерського обліку $€$ надання користувачам для прийняття рішень повної, правдивої та неупередженої інформації про фрінансовий стан та результати діяльності підприємства. Відповідно до ч. 1 ст. 9 Закону України «Про бухгалтерський облік та фрінансову звітність в Україні» [5], підставою для бухгалтерського обліку товарів та устаткування $€$ первинні документи, тобто вони є єдиним джерелом вхідної інформації у систему обліку й безпосередньо впливають на якість аналітичного і синтетичного обліку об'єктів готельно-ресторанного господарства.

Згідно з абз. 11 ст. 1 Закону України «Про бухгалтерський облік та фрінансову звітність в Україні», первинний документ - це документ, який містить відомості про господарську операцію.

Схоже визначення первинних документів міститься у Положенні про документальне забезпечення записів у бухгалтерському обліку, затвердженому Наказом Мінфіну від 24 травня 1995 р. № 88 [6].

У п. 2.1 зазначеного Положення відзначено, що первинні документи - це документи, створені у письмовій або електронній формі, які містять відомості про господарські операції, включаючи розпорядження та дозволи адміністрації (власника) на їх проведення.

Значення первинних документів у фрінансовогосподарській діяльності підприємства готельноресторанного господарства полягає не лише в тому, що вони $є$ підтвердженням правильності облікових даних. Первинні документи використовуються також для оперативного управління та спостереження за рухом товарів, встановлюють законність та доцільність тих чи інших операцій, допомагають виявити помилки в бухгалтерському обліку.

Зміст первинного документа, його інформаційна місткість, якість, репрезентативність та достовірність поданої інорормації є визначальними змістовними характеристиками, що залежать від правильності формулювання основних господарських операцій, пов'язаних із рухом товарів.

Облікова інфрормація фрормується поступово, шляхом послідовного проходження через етапи облікового процесу, зміст та послідовність яких визначені логікою процесу створення, оброблення та узагальнення інорормації, а також регламентовані нормативними документами [5]. 
Послідовність надходження інсрормації в обліковому процесі можна представити у вигляді трьох стадій. На стадії первинного обліку відбуваються сприйняття господарських операцій та їх запис у первинних документах. Поточний облік систематизує та групує показники документів у регістрах аналітичного ти синтетичного обліку. Підсумковий облік узагальнює показники за звітний період та передає інсрормацію користувачам.

Отже, на кожному етапі облікового процесу інорормація різниться за рівнями деталізації, змістом, структурою та призначенням, тому для її фрормування потрібні специфрічні фрорми носіїв інфрормації, які різняться між собою за змістом, будовою та структурою. Чітке та однозначне виділення й виокремлення кожної групи носіїв інфрормації (первинні документи - регістри обліку - форми звітності) дасть змогу встановити взаємозв'язки між їх показниками, забезпечити їх наступність та логічну послідовність у процесі фрормування підсумкової інсрормації.

Для прийняття виважених управлінських рішень необхідно правильно організувати процес обліку товарів, вирішити такі завдання, які забезпечать контроль за укладенням та виконанням договорів; документальним оформленням операцій $з$ надходження, використання та вибуття товарів; дотриманням правил організації їх зберігання; проведенням інвентаризації та своєчасним відображенням в обліку результатів; визначенням фрінансового результату від реалізації товарів; використанням програм складського обліку; правильністю розкриття інсоормації про товарні запаси в первинних документах, облікових регістрах та формах фрінансової звітності; запобіганням негативним результатам господарської діяльності підприємства.

Ідентифрікація господарських операцій, пов'язаних 3 основними напрямами руху товарів (надходження, розміщення та вибуття), дасть змогу уточнити основні об'єкти бухгалтерського обліку й контролю на всіх етапах просування товарів (готова продукція, товари, торгова надбавка, транспортно-заготівельні витрати, витрати на зберігання та внутрішнє переміщення, надлишки, нестачі, пересортування, доходи й витрати від реалізації, витрати на збут, знижки тощо).

На підприємствах готельно-ресторанного господарства можна окреслити три такі основні групи господарських операцій, пов'язаних з рухом товарів:

- надходження товарів, що поєднує господарські операції з власного виробництва, придбання, безоплатного одержання, внесків до статутного капіталу, обміну та одержання товарів на комісію; об'єктами обліку на цій стадії є готова продукція, товари, торгова надбавка й транспортно-заготівельні витрати;
- розміщення товарів, що поєднує господарські операції зі зберігання на складах, передачу у торгову залу та передачу структурним підрозділам; об'єктами обліку й контролю на цій стадії є витрати на зберігання та внутрішнє переміщення товарів, їх уцінку, дооцінку, нестачу і пересортування;

- вибуття, що поєднує господарські операції 3 реалізації, безоплатної передачі, обміну та розпродажу товарів; об'єктами обліку виступають доходи й витрати від реалізації, витрати на збут та знижки.

Виділені напрями руху товарів та господарські операції, які виникають у їх процесі, дадуть змогу уточнити склад об'єктів бухгалтерського обліку та контролю для вдосконалення їх організаційного забезпечення, проєктування ефективної системи документування обліку товарів та устаткування об'єктів готельно-ресторанного господарства.

Наприклад, можна класифікувати документи відповідно до етапів, пов'язаних з рухом та обліком товарних запасів, а саме:

- надходження товарних запасів на склад;

- надходження товарних запасів у торговельну залу;

- внутрішнє переміщення товарних запасів;

- реалізація товарних запасів;

- переоцінка товарних запасів;

- інвентаризація товарних запасів;

- визначення залишків товарних запасів на кінець звітного періоду;

- надання інорормації про товарні запаси управлінському персоналу;

- складання фрінансової звітності.

Відповідно до кожної запропонованої групи встановлюється необхідний перелік документів типової фрорми або власно розроблений. Правильно сорормована система документування операцій з руху товарних запасів створює базу даних інформаційного забезпечення управління товарними запасами та інформаційну систему підприємства.

Перелік документів для оорормлення руху товарів у системі первинного обліку на етапах надходження, складського обліку та внутрішнього переміщення, систематизовано в табл. 1.

Синтетичний та аналітичний облік проводиться за допомогою синтетичних та аналітичних рахунків, журналів, відомостей, оборотних відомостей та у фрінансовій звітності.

Загалом організація обліку товарів на підприємстві включає три основні етапи, такі як методичний, технічний та організаційний.

На першому етапі здійснюється вибір способів та прийомів, в основі яких лежать використання синтетичних та аналітичних рахунків, інвентаризація, документування, застосування методу подвійного запису, калькулювання, бухгалтерський баланс та фрінансова звітність.

На цьому етапі здійснюється вибір конкретного застосування елементів методу бухгалтерського 
Перелік документів первинного обліку для офрормлення руху товарів

Таблиця 1

\begin{tabular}{|l|l|}
\hline \multicolumn{1}{|c|}{ Надходження товарів } & Складський облік і внутрішнє переміщення товарів \\
\hline Рахунок-орактура & Картка складського обліку \\
\hline Накладна на відпуск товарно-матеріальних цінностей & Книга складського обліку \\
\hline Прибутковий ордер & Матеріальний ярлик \\
\hline Товарно-транспортна накладна & Накладна-вимога на відпуск (внутрішнє переміщення) \\
\hline Митні декларації & Накладна на відпуск товарно-матеріальних цінностей \\
\hline Сертифрікат відповідності (якості) & Реєстр приймання-здачі документів \\
\hline Акт приймання товарів за кількістю & \\
\hline Акт приймання товарів за якістю & \\
\hline Журнал обліку надходження товарів & \\
\hline Платіжні документи & \\
\hline
\end{tabular}

Джерело: побудовано авторами

обліку, а саме проводиться комплекс заходів, які забезпечують організацію первинного документування операцій, пов'язаних з надходженням, розміщенням та вибуттям товарів; встановлюються строки та порядок проведення інвентаризації товарів на підприємстві; вибирається метод оцінювання товарів під час надходження та вибуття; вибирається номенклатура рахунків (робочого плану рахунків) бухгалтерського обліку і розробляється структура субрахунків та аналітичних рахунків товарів, доходів і витрат від вибуття товарів; вибирається і затверджується перелік типових господарських операцій щодо відображення в обліку транспортно-заготівельних витрат, витрат на зберігання та внутрішнє переміщення, нарахування та списання торговельної надбавки; проводяться уцінка та дооцінка товарів, виявляються надлишки, недостачі та пересортування товарів, повернення бракованих товарів продавцю; визначаються перелік та фрорми внутрішньої звітності й джерел інфрормації для їх заповнення.
На цьому етапі для своєчасного та ефективного первинного обліку на підприємствах готельно-ресторанного господарства необхідно забезпечити чіткий порядок організації складання й опрацювання первинних документів, який називають графріком документообігу. Його метою $є$ прискорення руху носіїв інфрормації. Чим краще буде організовано і чим швидше відбуватиметься процес документообігу, тим ефективніше він буде для споживачів інорормації, які зможуть вчасно її отримати, ефективно впливати на ситуацію та здійснювати контроль за фрінансово-господарською діяльністю.

Документообіг на кожному підприємстві є індивідуальним і визначається виключно сферою його діяльності та особливостями його роботи. Документообіг затверджується наказом керівника підприємства. Зразок фрорми графіку документообігу подано у табл. 2.

Розрізняють два види графріків документообороту, а саме статичні й динамічні, що використовуються для досягнення певних цілей.

Графрік документообігу

Таблиця 2

\begin{tabular}{|c|c|c|c|c|c|c|c|c|c|c|c|c|c|c|}
\hline \multirow{2}{*}{ 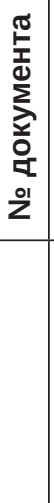 } & \multicolumn{5}{|c|}{ Створення документів } & \multicolumn{4}{|c|}{ Перевірка документа } & \multicolumn{2}{|c|}{$\begin{array}{c}\text { Обробка } \\
\text { документа }\end{array}$} & \multirow[t]{2}{*}{ 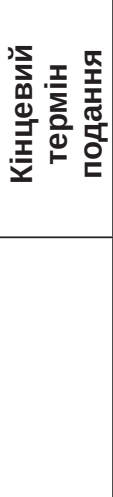 } & \multicolumn{2}{|c|}{$\begin{array}{c}\text { Передавання } \\
\text { до архіву }\end{array}$} \\
\hline & 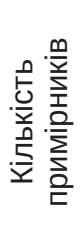 & 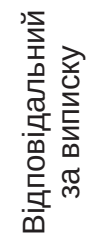 & 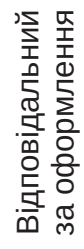 & 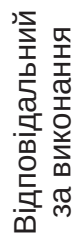 & 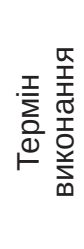 & 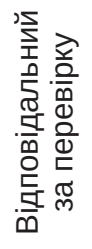 & 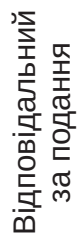 & 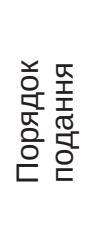 & 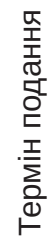 & 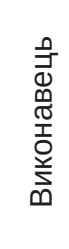 & 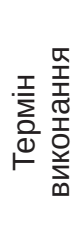 & & 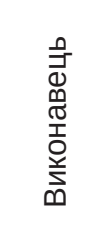 & 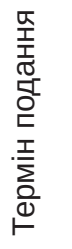 \\
\hline 1 & 2 & 3 & 4 & 5 & 6 & 7 & 8 & 9 & 10 & 11 & 12 & 13 & 14 & 15 \\
\hline & & & & & & & & & & & & & & \\
\hline & & & & & & & & & & & & & & \\
\hline
\end{tabular}

Джерело: побудовано авторами 
Динамічний грасрік документообігу відображає схему обміну документами, накладену на організаційну структуру підприємства. Складання таких графріків потребує детального дослідження руху документів від виконавця до виконавця та постійної фріксації цього руху.

Статичні грасріки документообігу залежно від специфріки діяльності підприємства показують порядок руху кожного виду документа, починаючи від його створення або отримання, реєстрації, затвердження, передачі, збереження та закінчуючи передачею в архів або знищенням.

У статичному графріку документообігу доцільно виділити такі етапи руху кожного документа, як створення документа (операція, яка реєструється документом, відповідальні виконавці, підписи посадових осіб і кількість примірників); надходження документа від сторонньої організації (терміни, відповідальні виконавці); затвердження документа (особа, що затверджує документ); реєстрація документа (терміни, відповідальні особи); передача документа сторонній організації (терміни, відповідальні особи); поточне збереження документа в організації (місцезнаходження, терміни, відповідальні особи); збереження документа в архіві організації (терміни, відповідальні особи); передача документа в архів (терміни, відповідальні особи); знищення документа.

Технічний етап передбачає вибір форми обліку, що найбільше відповідає галузі, розміру та організаційно-правовій формі підприємства. Тут вибирається спосіб оброблення облікової інфрормації, а саме некомп'ютеризований або комп'ютеризований; розробляється перелік фрорм облікових регістрів; встановлюється порядок здійснення записів у них.

За організацію роботи облікового апарату відповідає третій етап проєктування системи обліку товарів на підприємстві. Він включає встановлення лінійних і функціональних інформаційних зв'язків між бухгалтерією підприємства та підрозділами; фоомування оптимальної структури облікового апарату; організацію матеріального, інфрормаційного й технічного забезпечення; організацію захисту облікової інформації.

Суб'єктами організації бухгалтерського обліку $€$ керівники підприємства, а саме директор та головний бухгалтер, об'єктом - обліковий процес, праця виконавців, організаційне, інфрормаційне, технічне забезпечення обліку, тобто система бухгалтерського обліку.

Проблема організації обліку на кожному підприємстві готельно-ресторанного господарства полягає у запровадженні такої сукупності правил, реалізація яких забезпечила б максимальний ефеект від ведення обліку товарів, тому постановка та ведення обліку розпочинається з Наказу про облікову політику, в якому відображаються методологічні принципи обліку об'єктів обліку.
Загалом облікову політику підприємства щодо руху товарів можна розділити на методичну та організаційно-технічну частини. Методична частина включає облікові одиниці товарів, їх первинну оцінку, облік транспортно-заготівельних витрат, методи оцінювання під час вибуття, порядок нарахування торгової надбавки, ведення уцінки, норми природного убутку та перелік статей витрат обігу.

Організаційно-технічна частина облікової політики визначає матеріально-відповідальних осіб і розподіл їх обов'язків, засоби комп'ютерних технологій, перелік первинних документів та облікових регістрів, робочий план рахунків бухгалтерського обліку, форми внутрішньої звітності, склад інвентаризаційної комісії та строки інвентаризації.

Важливо відзначити існування формального підходу до розроблення облікової політики та приділення неналежної уваги деталізації її положень на деяких підприємствах. Це зумовлює використання альтернативних варіантів до облікового відображення операцій, пов'язаних з рухом товарів, що приводить до неможливості порівнювати інформацію, надану користувачам.

Висновки з проведеного дослідження. Отже, задля зниження трудомісткості облікових процесів, підвищення точності та оперативності обробки облікової інформації проєктування системи документування обліку товарів об'єктів готельно-ресторанного господарства необхідно проводити 3 огляду на раціональність ведення бухгалтерського обліку та дієвість системи внутрішнього контролю для задоволення інсрормаційних потреб власників щодо управління товарним асортиментом на всіх етапах руху товарів задля оптимізації товарообігу на підприємстві.

\section{БІБЛІОГРАФІЧНИЙ СПИСОК:}

1. Легенчук С., Вольська К., Вакун О. Документування в бухгалтерському обліку: процесний підхід : монограсрія. Івано-Франківськ : вид. Кушнір Г., 2016. $228 \mathrm{c}$.

2. Дударєва К. Обґрунтування ключових понять процесу документування. Проблеми теорії та методології бухгалтерського обліку, контролю і аналізу. 2015. № 2 (17). C. 91-99.

3. Левицька С., Осадча О. Концептуальні поняття складових документообігу на вітчизняних підприємствах. Вісник ЖДТУ. 2011. № 3 (57). С. 79-81.

4. Маренич Т. Документальне забезпечення записів у бухгалтерському обліку: аналіз новацій та напрями поліпшення. Актуальні проблеми інноваційної економіки. 2017. № 1. С. 76-79.

5. Про бухгалтерський облік і фрінансову звітність в Україні : Закон від 16 липня 1999 р. № 966-XIV. URL: http://zakon3.rada.gov.ua/laws/show/996-14 (дата звернення: 30.08.2021).

6. Положення про документальне забезпечення записів в бухгалтерському обліку: Наказ Міністерства 
фрінансів України від 24 травня 1995 р. № 88. URL: http://zakon0.rada.gov.ua/laws/show/z0168-95 (дата звернення: 30.08.2021).

\section{REFERENCES:}

1. Lehenchuk S., Volska K., Vakun O. (2016) Dokumentuvannia $v$ bukhhalterskomu obliku: protsesnyi pidkhid [Documentation in accounting: a process approach]. Ivano-Frankivsk: vydavets Kushnir H. (in Ukrainian)

2. Dudaryeva K. (2015) Obgruntuvannia kliuchovykh poniat protsesu dokumentuvannia [Justification of the key concepts of the documenting process]. Problemy teorii ta metodolohii bukhhalterskoho obliku, kontroliu i analizu, no. 2 (17), pp. 91-99.

3. Levyczka S., Osadcha O. (2011) Kontseptualni poniattia skladovykh dokumentoobihu na vitchyznianykh pidpryiemstvakh [Conceptual concepts of document circulation in domestic enterprises]. Visnyk ZhDTU, no. 3 (57), pp. 79-81.

4. Marenych T. (2017) Dokumentalne zabezpechennia zapysiv u bukhhalterskomu obliku: analiz novatsii ta napriamy polipshennia [Documentary maintenance of records in accounting: the analysis of innovations and directions of improvement]. Aktualniproblemy innovatsiinoi ekonomiky, no. 1, pp. 76-79.

5. Pro bukhhalterskyi oblik i finansovu zvitnist $v$ Ukraini: Zakon vid 16 lypnia 1999 r. № 966-XIV [The Law of Ukraine "On Accounting and Financial Reporting in Ukraine" No. 996-XIV of 16.07.1999]. Available at: http://zakon3.rada.gov.ua/laws/show/996-14 (accessed 30 August 2021).

6. Nakaz Ministerstva finansiv Ukrainy No. 88 "Pro zatverdzhennia Polozhennia pro dokumental'ne zabezpechennia zapysiv u bukhhalters'komu obliku" vid 24.05.1995 r. Available at: http://zakon0.rada.gov.ua/ laws/show/z0168-95 (accessed 30 August 2021). 